\title{
Contrast Agent CS-1000
}

National Cancer Institute

\section{Source}

National Cancer Institute. Contrast Agent CS-1000. NCI Thesaurus. Code C113648.

An aqueous colloidal nanoemulsion containing perfluorocarbon (PFC) polymers that can be used as a tracer for cell tracking purposes during fluorine-19 (19F) magnetic resonance imaging (MRI). Upon administration of the contrast agent CS-1000 to cells ex vivo, this agent freely enters the cells. Upon introduction of these cells into the patient and subsequent 19F MRI, the amount of fluorine can be detected and cellular persistence, survival and distribution of the treated cells can be assessed. The emulsion allows for fast entry of the fluorinated polymers into cells; the polymers do not degrade and remain in the cells. 